\title{
Serapan Fosfor dan Pertumbuhan Kedelai (Glycine max) pada Tanah Ultisol dengan Pemberian Asam Humat
}

\author{
Wahyuningsih ${ }^{1}$, Elly Proklamasiningsih ${ }^{1}$, Murni Dwiati ${ }^{1}$ \\ ${ }^{1}$ Fakultas Biologi, Universitas Jenderal Soedirman \\ email: risna.wahyuningsih@gmail.com
}

\begin{abstract}
Ultisol is one type of acid soils which has a high solubility of $\mathrm{Al}, \mathrm{Fe}$, and $\mathrm{Mn}$, and low contain of $\mathrm{P}$ and Mo. High $\mathrm{Al}$ and Fe solubility absorb phosphate so their soil phosphorus availability and uptake of $P$ for the plants are low. One effort to increase of soil phosphorous availability is with the application of humic acid. Humic acid is a polyelectrolyte macromolecules which have functional groups such as - $\mathrm{COOH}$, phenolic $\mathrm{OH}$, or alcoholic - $\mathrm{OH}$ so that humic acid has the ability to form complexes with metal ions. This research was conducted with the aim to: (1) know the effect of humic acid on $P$ uptake and growth of soybean plants (2) select the best concentration of humic acid in improving $P$ uptake and growth of soybean plants. The method used was experimental with Randomized Completely Block Design (RCBD). Grouping is based on the difference in light accept in the green house. Treatments were in the form of humic acid concentrations, with 5 different concentrations i.e. 0, 400, 800, 1200 and 1600 ppm. Varables were plant height, leaf area, fresh shoot plant weight, dry shoot plant weight, soil available $P$ and $P$ uptake by plant. Data were analyzed with analysis of Varians at a significant level at $95 \%$ and $99 \%$, then were continued with Least Significant Difference (LSD) test. The results showed that there was a significant effect of humic acid on $\mathrm{P}$ uptake and growth of soybean in the Ultisol. 1200 ppm humic acid was the most excellent treatment in spurring $\mathrm{P}$ uptake and growth of soybean Ultisol.
\end{abstract}

Keywords: Humic Acid, P uptake, Growth of Plants, soybean (Glycine max). Ultisols.

\begin{abstract}
Abstrak
Ultisol merupakan tanah masam yang memiliki kelarutan $\mathrm{Al}$, Fe, dan $\mathrm{Mn}$ tinggi, serta kandungan $\mathrm{P}$ dan Mo yang rendah. Kelarutan Al dan Fe yang tinggi menjerap fosfat, sehingga ketersediaan dan serapan $P$ bagi tanaman menjadi rendah. Salah satu upaya untuk mengatasi ketidaktersediaan $\mathrm{P}$ pada Ultisol yaitu dengan penambahan asam humat $(\mathrm{AH})$. Asam humat merupakan makromolekul polielektrolit yang memiliki gugus $-\mathrm{COOH},-\mathrm{OH}$ fenolat, maupun $-\mathrm{OH}$ alkoholat, sehingga asam humat berkemampuan untuk membentuk kompleks dengan Al dan Fe. Penelitian ini dilakukan dengan tujuan untuk: (1) mengetahui pengaruh asam humat terhadap serapan $\mathrm{P}$ dan pertumbuhan tanaman kedelai (2) menentukan konsentrasi asam humat yang paling baik dalam meningkatkan serapan $P$ dan pertumbuhan tanaman kedelai. Metode penelitian yang digunakan adalah eksperimental dengan Rancangan Acak Kelompok Lengkap (RAKL). Pengelompokan didasarkan atas perbedaan penerimaan cahaya matahari yang ada di rumah kaca. Perlakuan berupa 5 konsentrasi asam humat, yaitu 0, 400, 800, 1.200 dan 1.600 ppm. Variabel yang diukur meliputi tinggi tanaman, luas daun, bobot tanaman segar, bobot tanaman kering, kandungan $\mathrm{P}$ - tersedia tanah, dan serapan $\mathrm{P}$ tanaman. Data yang diperoleh dianalisis dengan analisis ragam pada tingkat kepercayaan $95 \%$ dan $99 \%$. Apabila analisis ragam berbeda nyata dan sangat berbeda nyata, maka dilanjutkan uji Beda Nyata Terkecil (BNT) antar perlakuan dengan tingkat kepercayaan $95 \%$ dan $99 \%$. Hasil penelitian menunjukkan bahwa asam humat berpengaruh terhadap serapan P dan pertum-buhan tanaman kedelai. Perlakuan 1200 ppm asam humat merupakan perlakuan yang paling baik dalam meningkatkan serapan $\mathrm{P}$ dan pertumbuhan tanaman kedelai
\end{abstract}

Kata kunci: asam humat, serapan P, pertumbuhan tanaman, Kedelai, Ultisol,

\section{Pendahuluan}

Ultisol merupakan salah satu tanah yang memiliki luasan sekitar $21 \%$ (40 juta $\mathrm{Ha}$ ) dari luas total daratan Indonesia 192 juta $\mathrm{Ha}$ (Barchia, 2009). Tanah Ultisol dapat dicirikan dengan tanah yang berwarna kuning kecoklatan hingga merah. Tekstur tanah Ultisol bervariasi dan dipengaruhi oleh bahan induk tanahnya. Tanah Ultisol yang berasal dari granit umumnya mempunyai tekstur liat berpasir, sedangkan tanah Ultisol dari batu kapur, andesit, dan tufa cenderung memiliki tekstur liat (klei) (Prasetyo \& Suriadikarta, 2006).

Tanah Ultisol memiliki potensi yang tinggi untuk dikembangkan menjadi lahan pertanian. Namun, pemanfaatannya menghadapi berbagai 
kendala karena $\mathrm{pH}$ tanah yang rendah. Rendahnya $\mathrm{pH}$ tanah tersebut berimplikasi terhadap kelarutan $\mathrm{Al}$, Fe, dan Mn yang tinggi serta ketersediaan $\mathrm{P}$, dan Mo yang rendah. Kandungan Al pada tanah Ultisol berkisar antara $3 \%$ dan $9 \%$, Fe 1,4\% dan 4\%. Sementara itu, kandungan $\mathrm{P}$ berkisar antara 0,04 dan $0,3 \%$. Kelarutan Al dan Fe yang tinggi menjerap fosfat, sehingga ketersediaan $P$ bagi tanaman menjadi rendah (Barchia, 2009).

Tanah Ultisol dapat dijumpai di daerah Banyumas, Desa Tanggeran, Kecamatan Somagede. Analisis kandungan $\mathrm{P}_{2} \mathrm{O}_{5}$ total tanah Ultisol di Desa Tanggeran sebesar 1.420 ppm. $\mathrm{P}_{2} \mathrm{O}_{5}$ tersedia yaitu sebesar 0,067 ppm. Berdasarkan kriteria Balai Penelitian Tanah (2005), kandungan $\mathrm{P}$ total di Desa Tanggeran sangat tinggi, dan $P$ tersedia sangat rendah.

Ketersediaan $\mathrm{P}$ pada tanah Ultisol dapat ditingkatkan dengan pemberian bahan organik. Peningkatan ketersediaan $\mathrm{P}$ akibat pemberian bahan organik terjadi karena, selama proses dekomposisi bahan organik akan dihasilkan asam humat ( humat. Asam humat memegang peranan penting pada lepasnya pengikatan $\mathrm{Al}$ dan $\mathrm{Fe}$, sehingga $P$ yang semula terjerap $\mathrm{Al}$ dan $\mathrm{Fe}$ menjadi tersedia (Herviyanti et al., 2012). Perlakuan asam humat diharapkan dapat memperbaiki ketersediaan hara pada Ultisol karena beberapa peneliti membuktikan bahwa asam humat efektif dalam meningkatkan pertumbuhan. Akinci et al. (2009) menyatakan bahwa asam humat dapat meningkatkan serapan unsur hara. Ameri et al (2013) menyatakan bahwa aplikasi asam humat dapat meningkatkan pertumbuhan dan hasil tanaman. Oleh karena itu, lahan Ultisol diharapkan dapat dimanfaatkan untuk budidaya tanaman kedelai.

Tanaman kedelai dapat tumbuh pada kondisi lahan yang kurang subur dan agak masam. Toleransi $\mathrm{pH}$ tanah sebagai suatu syarat tumbuh bagi tanaman kedelai adalah $\mathrm{pH}$ sekitar 5,8 dan 7 . Namun, pada pH kurang dari 5,5 pertumbuhan tanaman kedelai sangat lambat, karena kelarutan Al dan Fe tinggi (Najiyati \& Danarti, 1999). Kedelai yang digunakan dalam penelitian ini adalah kedelai varietas Burangrang. Kedelai ini merupakan salah satu varietas yang peka terhadap tanah masam. Aplikasi asam humat dalam meningkatkan $P$ diharapkan lebih responsif, sehingga dapat memacu pertumbuhan tanaman kedelai.

Tujuan penelitian ini adalah untuk (1) mengetahui pengaruh pemberian asam humat pada tanah Ultisol terhadap serapan $\mathrm{P}$ dan pertumbuhan tanaman kedelai. (2) mengetahui konsentrasi asam humat yang paling baik dalam meningkatkan serapan $\mathrm{P}$ dan pertumbuhan tanaman kedelai.

\section{Metode}

Penelitian dilaksanakan di rumah kaca, dan Laboratorium Fisiologi Tumbuhan Fakultas Biologi. Penelitian menggunakan metode eksperimental dengan Rancangan Acak Kelompok (RAKL). Percobaan ini menanam benih kedelai Burangrang pada $1 \mathrm{~kg}$ Ultisol/pot. Perlakuan yang dicobakan adalah 5 konsentrasi asam humat, yaitu $\mathrm{H}_{0}(0 \mathrm{ppm}), \mathrm{H}_{1}$ (400 ppm), $\mathrm{H}_{2}$ (800 ppm), $\mathrm{H}_{3}$ (1.200 ppm) dan $\mathrm{H}_{4}(1.600$ ppm). Setiap perlakuan dibuat 3 ulangan. Ulangan 1, 2, dan 3 diacak dan ditempatkan masing-masing pada blok 1, 2, dan 3. Pemblokan tersebut didasarkan pada perbedaan penerimaan sinar di rumah kaca.Variabel yang diamati adalah serapan $P$, tinggi tanaman, luas daun, bobot tanaman segar, dan bobot tanaman kering. Data yang diperoleh dianalisis dengan analisis ragam pada tingkat kepercayaan 95 \% dan 99 \%. Apabila analisis ragam berbeda nyata dan sangat berbeda nyata, maka dilanjutkan uji Beda Nyata Terkecil (BNT) antarperlakuan dengan tingkat kepercayaan $95 \%$ dan $99 \%$. Sebagai data pendukung diamati pula suhu, intensitas sinar, dan kelembaban udara di lokasi penelitian.

Pengukuran $\mathrm{P}_{2} \mathrm{O}_{5}$ total dilakukan menggunakan metode ekstraksi $25 \% \mathrm{HCl}$ dan Ptersedia tanah menggunakan metode Bray dan Kurtz I. Pengukuran P-tersedia dilaksanakan pada Ultisol sebelum dan setelah perlakuan asam humat. Pengukuran $\mathrm{P}$ tanaman dilakukan dengan metode destruksi basah pada 30 hst (hari setelah tanam). Metode analisis $\mathrm{P}$ tanah dan tanaman mengacu pada Sulaiman et al. (2005).

Penyiapan media tanam dilakukan dengan memasukkan tanah ke dalam ...? pot, masingmasing $1 \mathrm{~kg}$ Ultisol. $x x$ pot I masing-masing tanpa asam humat $\left(\mathrm{H}_{0}\right)$, yy pot II masing-masing ditambahkan $400 \mathrm{mg}$ asam humat $\left(\mathrm{H}_{1}\right), \quad z z$ pot III masing-masing ditambahkan $800 \mathrm{mg}$ asam humat $\left(\mathrm{H}_{2}\right)$, pp pot IV masing-masing ditambahkan $1.200 \mathrm{mg}$ asam humat $\left(\mathrm{H}_{3}\right)$, dan $q 9$ pot $\mathrm{V}$ masingmasing ditambahkan $1.600 \mathrm{mg}$ asam humat $\left(\mathrm{H}_{4}\right)$. Tanah dan asam humat pada setiap polibag dicampur hingga homogen, kemudian ditambahkan a $\mathrm{ml}$ air sampai kapasitas lapangan.

Penanaman kedelai dilakukan dengan cara menugalkan 1 benih kedelai pada tanah di setiap polibag. Selanjutnya, dilakukan pemeliharaan yang meliputi penyulaman, penyiraman, pengendalian gulma, hama, dan penyakit sesuai kondisi di lapangan. Pemanenan kedelai dilakukan pada 30 hst.

Pengukuran tinggi tanaman dan luas daun dilakukan pada 15 dan 30 hst. Pengukuran luas daun dilakukan dengan metode gravimetri (Sitompul \& Guritno,1995). Sementara itu, pengukuran bobot tanaman segar dan bobot tanaman kering dilakukan pada 30 hst. 


\section{Hasil dan Pembahasan}

Hasil pengukuran suhu di sekitar tanaman kedelai berkisar antara 28 dan $32{ }^{\circ} \mathrm{C}$, kelembaban udara 70,3 dan 89,7 \%, dan intensitas sinar berkisar antara 2.940 dan 17.980 lux. Kondisi lingkungan ini cukup baik untuk mendukung pertumbuhan dan perkembangan tanaman kedelai varietas Burangrang.

Hasil analisis ragam pemberian asam humat berpengaruh terhadap tinggi tanaman dan luas daun tanaman kedelai pada pengamatan $2 \mathrm{mst}$ maupun 4 mst. (Tabel 1).

Tabel 1. Tinggi Tanaman dan Luas Daun Kedelai pada tanah Ultisol dengan Penambahan Berbagai Konsentrasi Asam Humat pada Pengamatan 2 dan 4 mst.

\begin{tabular}{|c|c|c|c|}
\hline Umur & Perlakuan (ppm AH) & Tinggi Tanaman $(\mathrm{cm})$ & Luas Daun $\left(\mathrm{cm}^{2}\right)$ \\
\hline \multirow[t]{6}{*}{$2 \mathrm{mst}$} & $\mathrm{H}_{0}(0)$ & $20,300 a$ & $7,5770 \mathrm{a}$ \\
\hline & $\mathrm{H}_{1}(400)$ & $22,367 \mathrm{a}$ & $10,603 a$ \\
\hline & $\mathrm{H}_{2}(800)$ & $24,967 \mathrm{~b}$ & $13,367 b$ \\
\hline & $\mathrm{H}_{3}(1.200)$ & $32,000 \mathrm{~d}$ & $19,697 d$ \\
\hline & $\mathrm{H}_{4}(1.600)$ & $25,733 \mathrm{c}$ & $15,910 \mathrm{c}$ \\
\hline & BNT 0,05 & 2,825 & 3,51 \\
\hline \multirow[t]{6}{*}{$4 \mathrm{mst}$} & $\mathrm{H}_{0}(0)$ & $35,367 \mathrm{a}$ & $12,880 \mathrm{a}$ \\
\hline & $\mathrm{H}_{1}(400)$ & $51,667 \mathrm{a}$ & $26,517 \mathrm{a}$ \\
\hline & $\mathrm{H}_{2}(800)$ & $56,133 a$ & $28,410 a$ \\
\hline & $\mathrm{H}_{3}(1.200)$ & $87,467 \mathrm{c}$ & $30,683 \mathrm{~b}$ \\
\hline & $\mathrm{H}_{4}(1.600)$ & $67,033 \mathrm{~b}$ & 29,167 a \\
\hline & BNT 0,05 & 27,364 & 3,164 \\
\hline
\end{tabular}

Keterangan: Angka yang diikuti huruf yang sama tidak berbeda nyata antarperakuan pada uji BNT taraf kepercayaan $95 \%$

Aplikasi 1.200 ppm asam humat menunjukkan hasil tinggi tanaman dan luas daun tanaman kedelai terbaik pada pengamatan 2 mst maupun 4 mst. Artinya, aplikasi $1.200 \mathrm{ppm}$ asam humat merupakan aplikasi yang paling efektif dalam pertumbuhan tanaman di Ultisol. Hal ini berkaitan erat dengan peningkatan kelarutan $\mathrm{P}$ dan pasokan $\mathrm{N}$ dari asam humat yang dimanfaatkan oleh tanaman. Asam humat dengan kemampuannya untuk mengikat dan membentuk senyawa kompleks dengan ion logam akan mempengaruhi ketersediaan unsur hara $P$ yang dibutuhkan oleh tanaman untuk proses pertumbuhan. Selain ketersediaan $\mathrm{P}$ dalam tanah, pertumbuhan tanaman juga dipengaruhi oleh sifat fisika tanah yang baik, sehingga mampu menciptakan kondisi yang baik bagi pertumbuhan akar (Najiyati \& Danarti, 1999). Pemberian asam humat mampu memperbaiki tanah Ultisol yang umumnya kurang menguntungkan bagi pertumbuhan tanaman. Sifat fisika tanah yang baik dapat mempengaruhi ketersedian air serta unsur hara, sehingga hara akan lebih mudah diserap oleh akar tanaman dan mampu menstimulasi pertumbuhan.Unsur hara N, P, bersama Mg merupakan unsur hara yang berperan dalam meningkatkan luas daun tanaman. $\mathrm{N}$ merupakan unsur utama dalam pertumbuhan tanaman untuk pembentukan daun. $\mathrm{P}$ berfungsi sebagai penyusun protein dan $\mathrm{Mg}$ sebagai penyusun molekul klorofil yang berperan dalam proses fotosintesis. Hasil analisis ragam pemberian asam humat terhadap bobot tanaman kering menunjukkan bahwa aplikasi asam humat berpengaruh sangat signifikan terhadap bobot tanaman kering. (Tabel 2).

Tabel 2. Bobot tanaman kering pada Tanah Ultisol dengan Penambahan Berbagai Konsentrasi Asam Humat pada 4 mst.

\begin{tabular}{ccccc}
\hline $\begin{array}{c}\text { Perlakuan } \\
(\mathrm{ppm} \mathrm{AH})\end{array}$ & $\begin{array}{c}\text { Bobot Akar } \\
\text { Kering }(\mathrm{g})\end{array}$ & $\begin{array}{c}\text { Bobot Batang } \\
\text { Kering }(\mathrm{g})\end{array}$ & $\begin{array}{c}\text { Bobot Daun } \\
\text { Kering }(\mathrm{g})\end{array}$ & $\begin{array}{c}\text { Bobot Tanaman } \\
\text { Kering }(\mathrm{g})\end{array}$ \\
\hline 0 & $0,013 \mathrm{a}$ & $0,210 \mathrm{a}$ & $0,203 \mathrm{a}$ & $0,427 \mathrm{a}$ \\
400 & $0,050 \mathrm{c}$ & $0,310 \mathrm{a}$ & $0,310 \mathrm{c}$ & $0,670 \mathrm{a}$ \\
800 & $0,033 \mathrm{~b}$ & $0,340 \mathrm{a}$ & $0,343 \mathrm{c}$ & $0,717 \mathrm{a}$ \\
1200 & $0,057 \mathrm{c}$ & $0,510 \mathrm{c}$ & $0,380 \mathrm{~d}$ & $0,947 \mathrm{~b}$ \\
1600 & $0,037 \mathrm{~b}$ & $0,347 \mathrm{~b}$ & $0,267 \mathrm{~b}$ & $0,650 \mathrm{a}$ \\
BNT 0,05 & 0,001 & 0,131 & 0,04 & 0,131 \\
\hline
\end{tabular}

Keterangan: Angka yang diikuti huruf yang sama tidak berbeda nyata antar-perakuan pada uji BNT taraf kepercayaan $95 \%$. 
Aplikasi 1200 ppm asam humat memberikan hasil yang terbaik pada bobot tanaman kering. Hal ini seiring dengan semakin meningkatnya ketersediaan $\mathrm{P}$ dalam tanah. Peningkatan $\mathrm{P}$ tersedia dalam tanah ini mempengaruhi pula serapan $\mathrm{P}$ oleh tanaman. $\mathrm{P}$ yang diserap oleh tanaman mampu merangsang pembentukan akar, sehingga pertumbuhan tanaman menjadi lebih baik. Hal ini sesuai dengan pernyataan Hardjowigeno (2003), bahwa P dapat memacu pertumbuhan akar dan pembentukan sistem perakaran yang baik pada tanaman muda. Jika sistem perakaran baik, maka penyerapan hara juga baik, sehingga proses metabolisme berjalan sempurna. Oleh karena itu, pembentukan jaringan penyusun organ juga baik.

Hasil analisis ragam pemberian asam humat terhadap serapan $\mathrm{P}$ kedelai pada pengamatan 4 mst menunjukkan hasil yang signifikan.

Tabel 3. Serapan $\mathrm{P}$ tanaman pada Ultisol dengan penambahan berbagai konsentrasi asam humat pada pengamatan 4 mst.

\begin{tabular}{cc}
\hline Perlakuan (ppm AH) & Serapan P $(\mathrm{mg} / \mathrm{tnm})$ \\
\hline $\mathrm{H}_{0}(0)$ & $1,699 \mathrm{a}$ \\
$\mathrm{H}_{1}(400)$ & $2,215 \mathrm{a}$ \\
$\mathrm{H}_{2}(800)$ & $2,391 \mathrm{a}$ \\
$\mathrm{H}_{3}(1.200)$ & $3,447 \mathrm{c}$ \\
$\mathrm{H}_{4}(1.600)$ & $2,809 \mathrm{~b}$ \\
\hline BNT 0,05 & 0,939
\end{tabular}

Keterangan: Angka yang diikuti huruf yang sama tidak berbeda nyata anatarperlakuan pada Uji BNT taraf kepercayaan $95 \%$.

Dari Tabel 3. dapat dilihat pemberian asam humat meningkatkan serapan $P$ kedelai. Serapan $P$ meningkat seiring dengan meningkatnya ketersediaan $P$ dalam tanah. Hal ini sesuai dengan pendapat Hakim et al. (1989), bahwa penambahan asam humat ke dalam tanah Ultisol dapat meningkatkan kelarutan fosfat dengan mengurangi aktivitas (konsentrasi) ion $\mathrm{Al}$ dan $\mathrm{Fe}$ melalui khelasi, sehingga $P$ yang semula terjerap oleh kedua ion tersebut terlepas dan menjadi tersedia (Minardi, 2006).

Pemberian 1.200 ppm asam humat menunjukkan pertumbuhan tanaman yang paling baik dan serapan $P$ dalam tanaman juga paling tinggi diantara perlakuan yang dicobakan. Hal ini menunjukkan bahwa $P$ yang diserap oleh tanaman mendukung pertumbuhan tanaman.

\section{Simpulan}

Berdasarkan hasil dan pembahasan, maka dapat diambil kesimpulan sebagai berikut :

1. Asam humat berpengaruh terhadap serapan $P$ dan pertum-buhan tanaman kedelai.

2. Perlakuan 1200 ppm asam humat merupakan perlakuan yang paling baik dalam meningkatkan serapan $\mathrm{P}$ dan pertumbuhan tanaman kedelai.

\section{Daftar Referensi}

Akinci, S., Büyükkeskin, T., Eroğlu, A., Erdoğan, B. E. 2009. The Effect of Humic Acid on Nutrient Composition in Broad Bean (Vicia faba L.) Roots. Not Sci Biol 1 (1), 81-87

Ameri. A., Aminifard, M. H., Fatemi, H., Aroiee, H. 2013. Response of growth and yield of
Ocimum basilicum with application of Humic acid. Angewandten Biologie Forschung, 1 (1) : 1-6

Balai Penelitian Tanah. 2005. Petunjuk Teknis Analisis Kimia Tanah, Tanaman, Air, dan Pupuk. Badan Penelitian dan Pengembangan Pertanian, Departemen Pertanian. Bogor: Agro Inovasi.

Barchia, M.F., 2009. Agroekosistem Tanah Mineral Masam. Yogyakarta: Gadjah Mada University Press.

Hakim, N., Nyakpa, M.Y.,Lubis, A.M., Nugroho, S.G.,Saul, M.R., Diha, A., Bailey, H.H., 1989. Dasar-Dasar IImu Tanah. Lampung: Universitas Lampung. 488 hal.

Hardjowigeno, S., 2003. Ilmu Tanah. Jakarta: Akademika Presindo.

Herviyanti., Ahmad, F., Sofyani, R., Darmawan., Gusnidar dan Saidi, A., 2012. Pengaruh Pemberian Bahan Humat dari Ekstrak Batubara Muda (Subbituminus) dan Pupuk P Terhadap Sifat Kimia Ultisol serta Produksi Tanaman Jagung (Zea Mays L.). J. Solum,11(1), pp.15-24.

Minardi, S., 2006. Peran Asam Humat dan Fulvat dari Bahan Organik dalam Pelepasan $P$ Terjerap pada Andisol. Ringkasan Disertasi. Program Pascasarjana Universitas Brawijaya. Malang.

Najiyati, S., dan Danarti. 1999. Palawija, Budidaya, dan Analisis Usaha Tani. Jakarta: Penebar Swadaya 
Prasetyo, B.H., dan Suriadikarta, D.A., 2006. Karakteristik, Potensi, dan Teknologi Pengelolaan Tanah Ultisol untuk Pengembangan Pertanian Lahan Kering di Indonesia. Jurnal Litbang Pertanian, 25(2), pp. 39-46.

Sitompul, S.M. dan Guritno, B., 1995. Analisis Pertumbuhan Tanaman. Yogyakarta: Gadjah Mada University Press.
Sutejo, M.M., 2002. Pupuk dan Cara Pemupukan. Jakarta: Reneka Cipta. 177 hal.

Yuliandri., Jamilah., dan Ediwirman., 2014. Efisiensi Pemupukan dengan Asam Humat Terhadap Pertumbuhan Bibit Kelapa Sawit (Elaeis Guineensis Jacq.) pada Ultisol di Main Nursery. Laporan Penelitian. Padang: Program Studi Agroteknologi Fakultas Pertanian Universitas Tamansiswa. 